\title{
EFFECTIVENESS OF EDUCATION FOR KNOWLEDGE USE OF GENITALIA ANTISEPTICS FOR ADOLESCENTS
}

\author{
Dwi Sogi Sri Redjeki \\ STIKES Sarimulia, Indonesia \\ rinacubby72@gmail.com
}

\author{
Hendy Agus Rochyanto \\ STIKES Sarimulia, Indonesia \\ hendyagus@gmail.com
}

\begin{abstract}
This study aims to determine the level of effectiveness before and after being given education about the use of antiseptic genitals to know about young girls in Senior High School 11 Banjarmasin (SMAN 11 Banjarmasin). Research using Quantitative approach with Pre-Experimental Design method and One Group Pretest Posttes design is a research done by giving Pretest first before given intervention. Technique Data collection is done by giving Pre Test before, then result collected. After that done Post Test with the same problem, then the result is compared between Pre Test and Post Test by using SPSS Test, where previously done Normality test to know the data is normal distribution or not because the sample in this study amounted to 97 respondents then the researchers used the normality test with Test Kolmogorov Sminov. Research results show that of the research the effectiveness of knowledge before being given education on the use of antiseptic genitalia most of the respondents have enough knowledge that is 70 students (73\%). In this study it is known that the effectiveness of knowledge before being given education about antiseptic genitalia most of the whiteness of respondents have enough knowledge category that amounted to 70 female students (73\%), while knowledge of less 14 students (14\%) and good category amounted to 14 female students (14\%). There are differences in effectiveness before and after the way of education The use of antiseptic genitals against the knowledge of young women in SMAN 11 Banjarmasin, with level of significance equal to $95 \%$ with value of $\alpha=0,05$ which mean with value is expected possibility failure in this research $5 \%$.
\end{abstract}

Keywords: effectiveness of education, genitalia antiseptics, adolescents

\section{INTRODUCTION}

Many women in Indonesia use vaginal cleanser products, even every day popping up ads that offer powerful efficacy vagina cleaning products. While cleaning the vagina with a cleaning fluid (Antiseptic) can kill Lactobacillus bacteria that are useful for maintaining the acidity of the vagina [5]. Feminine cleansers generally contain many chemical compounds such as Petroleum, Syntetic Cheminal, and Petrocheminal (Chemicals Hamful) contents that can damage the skin and environment. If continued use of soap is increasingly eroding the bacteria Doderlyne (good bacteria) and other bacteria more easily enter the vagina. If this continues to cause whitish, pelvic inflammatory disease (PRP), genital infection, even one of the triggers Cervical Cancer [2].

Generally washing the vagina is often done after urinating with water or with water and soap that is generally done to clean the genitals. The act of inserting fluid into the vagina. In Indonesia the action is generally done after urination. The liquid used is usually only water or water with soap. There is a traditional ingredient used on the action, but it is often used by the mother after childbirth under normal circumstances. The vagina has a distinctive odor, but if we do not keep the vagina clean and if any infection can cause unpleasant odor, sting and fishy. Therefore, keeping the vagina clean is one of the most important things. One reason women do vaginal rinse because they feel disturbed by the smell that is not. They spray the vagina with commercial ingredients or traditional ingredients to make the vagina drier, more comfortable, prevent infection, eliminate leucorrhoea, cleanse the remaining blood after menstruation and avoid sexually transmitted diseases. Though it is more harm than profit [6].

Generally washing the vagina is often done after urinating with water or with water and soap that is generally done to clean the genitals. The act of inserting fluid into the vagina. In Indonesia the action is generally done after urination. The liquid used is usually only water or water with soap. There is a traditional ingredient used on the action, but it is often used by the mother after childbirth under normal circumstances. The vagina has a distinctive odor, but if we do not keep the vagina clean and if any infection can cause unpleasant odor, sting and fishy. Therefore, keeping the vagina clean is one of the most important things. One reason women do vaginal rinse because they feel disturbed by the smell that is not. They spray the vagina with commercial ingredients or traditional ingredients to make the vagina drier, more comfortable, prevent infection, eliminate leucorrhoea, cleanse the remaining blood after menstruation and avoid sexually transmitted diseases. Though it is more harm than profit [6].

According to WHO (World Health Organization) almost all women and adolescents have experienced whiteness, $60 \%$ in adolescents (15-22 years) and $40 \%$ in women (23-45 years). $75 \%$ of women in Indonesia must experience whiteness at least 1 time in their life (Suryandari, 2013). Research on Obstetrics Gynecology RSCM (Sianturi 1990-1995) received $2 \%$ data (age 11-15 years), 12\% (age 16-20 years) of 223 teenagers infected in the genital area (Vulvo Vaginitis), Microorganisms belonging to STIs (Infectious Infection Sex) (Arrixs, 2008). One of the reproductive health problems associated with STIs (infectious sex transmission) that is often experienced by young women is whitish even $90 \%$ of cases of cervical cancer in Indonesia is characterized by vaginal discharge [3]. According to [4], an obstetrician in her journal entitled "Acute Vulvovaginalis" women who experience vaginal discharge is very large that is $75 \%$ of women experience leucorrhoea at least 1 time in their life usually between 2 or more times. 
One consequence is due to lack of understanding of Personal Hygiene on the genitalia of the occurrence of reproductive health disorders such as: leucorrhoea, Urinary Tract Infection (UTI), Pelvic Inflammatory Disease (PRP) and the possibility of cervical cancer (Ca.Serviks) Both about Personal Hygiene in the genitalia so that adolescents can avoid the threat of reproductive disease [8]. Various studies on adolescents show that teenagers are often wrong in cleaning up the genitalia, for example: teens are often wrong in washing the genitals from the back to the front, cleaning the genitals using ordinary soap or cleaning fluids that are not clear, Perfume in the vagina (Handayani, 2011). This shows that adolescents need to be given good and positive information through health workers, parents, peers and teachers [1].

Based on preliminary study conducted on Thursday, January 19, 2017, data from Senior High School 11 Banjarmasin (SMAN 11 Banjarmasin), which has total students from X-XII class with total class of 20 rooms and 672 people with total number of students of class X as many as 248 people. At the time of the study, the researchers asked 10 students of class $\mathrm{X}$ to get the result of 7 students who did not know the antiseptic effect on the genitalia but using it (3 people use since class VII SMP, and 4 people use since they feel the whiteness), 3 students do not know Altogether about antiseptic genitalia and not using it. Recognition with one of the teachers in this school has never been any research on how to use antiseptic on genitalia and 10 schoolgirls in this school also informed that the lesson about how to use antiseptic on genitalia have never been given in this school.

\section{METHODS}

The location of research has been conducted at SMAN 11 Banjarmasin. Population in this research is all student of class $\mathrm{X}$ at SMAN 11 Banjarmasin which amounts to 129 female students. Research using Quantitative approach with Pre-Experimental Design method and One Group Pretest Posttes design is a research done by giving Pretest first before given intervention. After being given intervention, then done Posttest (Hidayat, 2014). Sampling method by Simple Random Sampling, where the population is reduced by Taro Yamane formula, then the sample amounted to 97 female students. Data was collected using questionnaire, the result was tested using Paired T-Test with degree of trust $(0,05) 95 \%$.

Technique Data collection is done by giving Pre Test before, then result collected. After that done Post Test with the same problem, then the result is compared between Pre Test and Post Test by using SPSS Test, where previously done Normality test to know the data is normal distribution or not because the sample in this study amounted to 97 respondents then the researchers used the normality test with Test Kolmogorov Sminov. If the data is normal then tested Paired T Test and if abnormal data can use Wilcoxon test. The sequence of data collection as follows:

1. Explanation on the respondent about the research objectives.

2. Explanation of the benefits of research.

3. Explanation of the questionnaire.

4. Pre Test and Pre Test.

5. Provision of education on the use of genital antiseptics.

6. Using the same questionnaire as Pre Test then Post Tets are given after the education is given.

7. Pre Test and Post Test results are collected and viewed to their effectiveness.

\section{RESULT}

The results of this research are presented in two levels of analysis, namely univariate analysis to describe the frequency distribution of each research variable and bivariate analysis to describe between research variables, whether there is a relationship or no relationship between two variables, in the study to determine whether there is effectiveness of giving Educate how to use antiseptic genitalia to knowledge of young woman in SMAN 11 Banjarmasin.

Table 1

Frequency Distribution Before Given Education How to use Antiseptic Genitalia to Young Women Knowledge at SMAN 11 Banjarmasin (Pre-Test)

\begin{tabular}{ccc}
\hline Knowledge of Responden & Frequence & \% \\
\hline Good & 13 & 13 \\
Enough & 70 & 73 \\
Less & 14 & 14 \\
\hline Total & 97 & 100 \\
\hline
\end{tabular}

Table 2

Frequency Distribution After Educated How to use Antiseptic Genitalia on Young Women Knowledge In SMAN 11 Banjarmasin (Post-Test)

\begin{tabular}{ccc}
\hline Knowledge of Respondents & Frequence & \% \\
\hline Good & 58 & 60 \\
Enough & 29 & 30 \\
Less & 10 & 10 \\
\hline Total & 97 & 100 \\
\hline
\end{tabular}


Table 3

Distribution of Educational Effectiveness of Antiseptic Use of Genitalia on Young Women Knowledge In SMAN 11 Banjarmasin (Pretest and Post-Test)

\begin{tabular}{ccccc}
\hline \multirow{2}{*}{ Knowledge of Respondents } & \multicolumn{2}{c}{$\begin{array}{c}\text { Before being } \\
\text { Educated }\end{array}$} & \multicolumn{2}{c}{$\begin{array}{c}\text { After being } \\
\text { Educated }\end{array}$} \\
\cline { 2 - 5 } & Frequence & $\mathbf{\%}$ & Frequence & $\%$ \\
\hline Good & 13 & 13 & 58 & 60 \\
Enough & 70 & 73 & 29 & 30 \\
Less & 14 & 14 & 10 & 10 \\
\hline Total & 97 & 100 & 97 & 100 \\
\hline
\end{tabular}

a. Knowledge of young women before being given education about genital antiseptics (pre test)

Based on Table 1 students who have knowledge "good" amounted to 13 female students (13\%), knowledgeable "enough" amounted to 70 female students $(73 \%)$ and 14 students (14\%). So the amount of knowledge of female students is the knowledge in the category of "enough".

b. The knowledge of young women after being given education about genital antiseptics (post test)

Based on Table 2 students who have knowledge "good" amounted to 58 female students $(60 \%)$, knowledgeable "enough" amounted to 29 female students (30\%) and the less knowledge "less" as much as 10 female students (10\%). Then the highest amount of knowledge is the category of knowledge "good".

c. Knowledge before and after being given education about antiseptic of genitalia to knowledge of young woman in SMAN 11 Banjarmasin

Based on the table of 3 students who have knowledge of "good" before being given education about the use of genital antiseptic amounted to 13 female students (13\%) and after being given the method of using genitalia antiseptic amounted to 58 students $(60 \%)$ this illustrates that the change of knowledge from before given education And after being educated, who had "enough" knowledge before being given an education on how to use genitalia's antiseptic method amounted to 70 female students $(73 \%)$ and after being given education the use of genetic antiseptic amounted to $29(30 \%)$, and who had knowledge less before being educated on how to use the genitalia antiseptic amounted to 14 female students (14\%) and after being educated how the use of genital antiseptic amounted to 29 female students (30\%), and who had" less "knowledge before being given education how to use how to use Antiseptic genitalia amounted to 14 female students (14\%) and after being educated how the use of genetic antiseptic amounted to 10 female students $(10 \%)$.

\section{DISCUSSION}

In this discussion will be discussed about the effectiveness before and after being given an education how to use antiseptic genitalia to the knowledge of young girls in SMAN 11 Banjarmasin. The effectiveness of knowledge before being given education how to use antiseptic genitalia to knowledge of young woman in SMAN 11 Banjarmasin.

Based on the results of the research on the table 1 the effectiveness of knowledge before being given education on the use of antiseptic genitalia most of the respondents have enough knowledge that is 70 students $(73 \%)$, while the knowledgeable "less" amounted to 14 female students (14\%), and knowledgeable " Good "amounted to 13 female students $(13 \%)$. So the result of knowledge at the time of Pre-test result is "enough" with the highest amount.

This is also in line with the results of Shanti's (2016) study, namely: Knowledge level of teenage girls about the use of sufficient cleansing soap (63.3\%) in Al-Munawir Salafiyah, Bantul, Yogyakarta. Where in the research that researchers do is at the time of pretest knowledge of young women about the use of genitalia antiseptic like soap pengkih femininity in the category enough with the number of 70 students $(73 \%)$ of a total of 97 female students.

Usually in adolescents especially those who are in junior high school age ranges 12-15 years and high school with the age range 16-19 years, which is said adolescent transition, the transition period between childhood and adulthood. Usually teenagers at this age stage are very easy to receive information they get from mass media, magazines, newspapers, television, internet, radio, friends, society and the environment around them. So it is easy to obtain information and will make them receive the wrong information and the right information they receive without them know which is true and which is not true (Handayani, 2011).

Various studies on adolescents also show that teenagers are often wrong in cleaning up the genitalia, for example, teenagers are often wrong in washing the genitals from the back to the front, cleaning the genitals using ordinary soap or cleaning fluid that is not clear the composition of the womb, or sow powder, even spray Perfume in the vagina (Handayani, 2011). This shows that adolescents need to be given good and positive information through health workers, parents, peers and teachers [1].

The effectiveness of knowledge after being given education on how to use antiseptic genitalia to the knowledge of young women in SMAN 11 Banjarmasin. Based on the results of the research in table 2, the effectiveness of knowledge after being given a way of using antiseptic genitalia most of the respondents are well knowledge of $58(60 \%)$ while 29 students $(30 \%)$ and those with enough knowledge are 10 students (10\%) So that there is effectiveness before education is given and compared to after being educated about how genital antiseptics are used. 
Adolescent health education is important for teenagers to get them true and accurate information about reproductive health. Therefore it is necessary to hold more activities involving teenagers, especially in conducting counseling and reproductive health education so teenagers do not need to find out their own information about reproductive health problems that sometimes can not be Justified the truth (Notoatmodjo, 2010).

In accordance with the purpose of providing education on antiseptic genitalia in adolescent girls, one of the researchers who took the theory based on that is: based on the relation with healthy restrictions, where the example is related to the purpose of health education for example to change one's behavior from unhealthy behavior into behavior Healthy, in this case the researcher aims to provide information about how the use of genital antiseptics where this should not be done too often or for adolescents should not use too early. And after getting education through research instrument that is kuesioner (ketioner same with Pretest) turns out result change where respondent know and its knowledge in good category.

Knowledge before and after being given education about antiseptic genital to knowledge of young woman in SMAN 11 Banjarmasin. Based on this research got the result that is difference of effectiveness of knowledge before and after given education how to use antiseptic of genitalia at adolescent girl at SMAN 11 Banjarmasin with level of significance equal to $95 \%$ with value of $\alpha=0,05$ which mean with value is expected possibility failure in this research $5 \%$ to obtain a high confidence level with the test results Paired TTest value $\mathrm{p}<\alpha$ with $\mathrm{p}=0,000$ and $\alpha=0.05$ then $\mathrm{p}<\alpha$ found that $\mathrm{Ha}$ accepted and Ho rejected means there are differences in effectiveness before and after done pendididikan way The use of antiseptic genitalia against the knowledge of young women in SMAN 11 Banjarmasin.

In this study it is known that the effectiveness of knowledge before being given education about antiseptic genitalia most of the whiteness of respondents have enough knowledge category that amounted to 70 female students $(73 \%)$, while knowledge of less 14 students (14\%) and good category amounted to 14 female students (14\%). This happens because they often get this information through the mass media but they do not really understand about these female cleaners, they know it is good to use everyday because the ads on television are offering good offers and benefits about genital antiseptics.

The effectiveness of knowledge after being given education about the antiseptic of genitalia, experiencing the change of knowledge of the respondents into good category amounted to 58 students $(60 \%)$ where before given enough knowledge of knowledge of respondents, it shows the change of Pre Test and Post Test. Based on the description above, we get the effectiveness of giving education about antiseptic genitalia. Where respondents who initially did not know at all became aware of the use of antiseptic genitalia. And after being given education 10 respondents are still included in the category of "less" and 29 respondents are categorized "enough" this is because at the time given their education sitting behind, not feeling interested, feeling tired, lazy to read and follow friends answer.

The same study was also conducted by Wandha with the title "The Effectiveness of Health Education on Personal Hygiene of Women Against Women's Knowledge and Attitudes in Handling Whitish" with the result of statistical test conducted by using t-dependent test, $\mathrm{p}=0.000$, Differences in knowledge before and after health education. From the results of statistical tests performed by using tdependent test, obtained $p$ value $=0.034$, then there are differences in attitude before and after given health education. So based on the results of statistical tests found that health education provided effective.

In addition, the results of this study are not in line with the results of research conducted by Elvika with the title "Young Women Knowledge About the Use of Feminine Cleansing Soap" obtained the level of knowledge of teenage girls about the use of soap cleanser femininity category enough $(63.3 \%)$ in Pondok Pesantren Al-Munawir Salafiyah Class, Krapyak, Bantul, Yogyakarta. Based on the discussion of research results, previous extension methods conducted Pre Test and after that done Post Test can affect the effectiveness of education provided. Similarly, the researchers found that there was a difference in the effectiveness of knowledge before and after education on antiseptic genitalia to the knowledge of young women in SMAN 11 Banjarmasin.

\section{CONCLUSION}

Based on the results of the research the effectiveness of knowledge before being given education on the use of antiseptic genitalia most of the respondents have enough knowledge that is 70 students (73\%). In this study it is known that the effectiveness of knowledge before being given education about antiseptic genitalia most of the whiteness of respondents have enough knowledge category that amounted to 70 female students $(73 \%)$, while knowledge of less 14 students (14\%) and good category amounted to 14 female students (14\%). There are differences in effectiveness before and after the way of education The use of antiseptic genitals against the knowledge of young women in SMAN 11 Banjarmasin, with level of significance equal to $95 \%$ with value of $\alpha=0,05$ which mean with value is expected possibility failure in this research $5 \%$.

\section{ACKNOWLEDGMENTS}

I am very grateful to High School of Health Sciences Sari Mulia Banjarmasin who has given me permission to do research. who has helped and advice in making this Thesis and thanks to SMAN 11 Banjarmasin who has given permission and is willing to Become a place of research.

\section{REFERENCES}

[1] Fitriyah. 2013. History of Reproductive Health of Adolescents. Biometrics And Population. 
[2] Kusmiran. 2012. Reproductive Health Teens and Women. Jakarta: Salemba Medika.

[3] Limia. 2007. Prevelencia Of trichhomonas, Bacterial Vaginosis and Candidiasis in Women Attending. STI \& Gynocologic Clinic UingImmunologic Latex Agglutination Test. Http://ispub.com/ostia. Accessed on January 17, 2017.

[4] Linda. 2007. Acute Vulvo-Vaginalis. http://content.nejm.org/cgi. Accessed on January 17, 2017.

[5] Maytasari. 2010. Differences Effect Antifungi Essential Oil Green Leaf Sirih, Essential Oil Red Leaf Betel and Resik V Soap Bet on Album Candida Albicans in Vitro. Surakarta: Faculty of Medicine, Sebelas Maret University.

[6] Pribakti. 2012. Tips and Tricks Caring for Intimate Organ. Jakarta: CV Sagung Seto.
[7] Sari Mulia Health Sciences College. 2016. Final Project Guide. Banjarmasin: Sari Mulia Health Sciences College.

[8] Sandriana. 2014. Personal Hygiene Genitalia Santriwati Behavior in Pesantren Putri Ummul Mukminin Makassar South Sulawesi. Makassar: FKM Hasanuddin University.

[9] Suryandari. 2013. Relationship Use Soap Cleaning Femininity With Occurrence Whitish In Women Aged Fertile (WUS) in the Village Karang Jeruk District Jatirejo Mojokerto regency. Journal of Health Sciences of Majapahit Health Polytechnic. Volume 5.

[10] WHO. 2014. Global Adults report 2013. http://apps.who.int/iris/bitstream/10665/91355/1/97892 41564656_eng.pdf. Accessed December 5, 2016. 